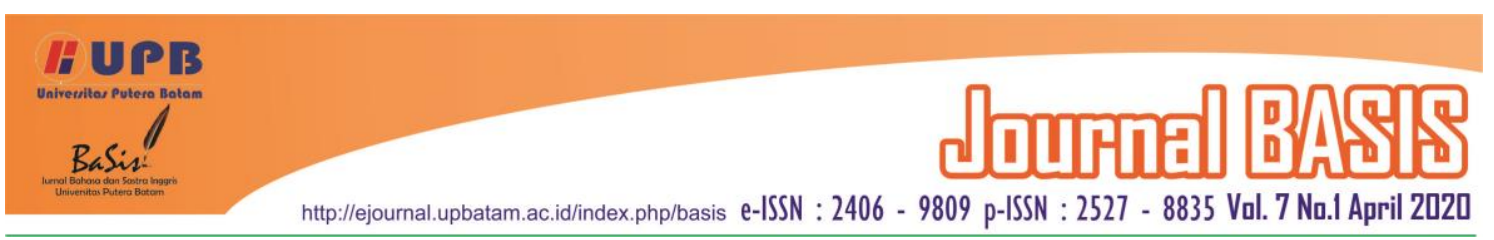

\title{
THE CORRELATION BETWEEN STUDENTS' READING HABIT AND THEIR READING COMPREHENSION
}

\author{
Fitri Dewi Sartika ${ }^{1}$ \\ Baturaja University, Baturaja, Indonesia \\ fitridewisartika@gmail.com \\ Nurul Afifah ${ }^{2}$ \\ Baturaja University, Baturaja, Indonesia \\ nurulafifah122@gmail.com \\ Yentri Anggraini $^{3}$ \\ Baturaja University, Baturaja, Indonesia \\ Anggeraini.yentr@yahoo.com
}

\begin{abstract}
The aim of this study was to observe on the correlation between students' reading habit and their reading comprehension of eleventh grade at SMA Negeri 1 Madang Suku 3 OKU Timur. In this quantitative study with correlational study, the writer used questionnaire and test to collect the data. The questionnaire measured students' reading habit and test measured students' reading comprehension. Populationof this study was all the eleventh grade students of SMA Negeri 1 Madang Suku 3 OKU Timur in academic year 2018/2019 were 124 student and took sample by using purposive sampling were 64 students. Based on the finding, the mean score of questionnaire was 60,89 and mean score of students' reading comprehension was 56,94 which was in moderated category. The writer found that there was significantly correlation between students'reading habit and their reading comprehension the correlation coofficient was 0,555 . It meant that alternative hypothesis (Ha) was accepted and null hypothesis was rejected in other word there was any significant correlation between students' reading habit and their reading comprehendion in medium correlation. As the conclusion,reading habit was not only aspect that influenced strudent reading comprehension that many factor also influenced the reading comprehension: internal factor (intellectual, language skills, psychological, environment, experience) and external factor (facilities, time to learning).To have good reading comprehension the student should know aspects reading comprehension were ability of association, conception ability, perception ability, syntactic ability - semantic ability and cognitive understanding.
\end{abstract}

Keywords : Correlation; Reading Habit; Reading Comprehension.

\section{INTRODUCTION}

In Indonesia, the education governments establish nglish as a compulsory subject start from Junior High School until University level. Moreover, English is one of the subjects that tested in the national final exam. English has four skills including reading, listening, speaking and writing, and has two components language including vocabulary and structure. Among those skills and components, reading becomes the main emphasis in learning language. Through reading, students also are able to learn speaking, listening, writing, structure, pronunciation and vocabulary. According to Patel and Jain (2008) reading is most useful and important skill for people, this skill more important than speaking and writing.

Based on the results of a survey of international institutions engaged in 
education, the United Nation Education Society and Cultural Organization (UNESCO), interest in reading the population of Indonesia is far below Asian countries. Indonesia seems to have a lot to learn from developed countries that have a fairly high reading tradition. Japan, America, Germany, and other developed countries whose people have a tradition of reading books, so rapidly its civilization. . In Indonesia this habit has not been seen. The habit of people who made books as friends, on buses, people take advantages of productive activities, namely reading books.

Complaints about students' low reading habits cannot be said to be teacher's fault in the school concerned. But this must be returned again to the habit of reading when students are still kids. Growing reading habits must start in the family. Parents play an important role in growing their children's reading habit. Reading activities need to be accustomed from an early age, namely from children to recognize letters. Make reading activities a necessity and a fun thing for students. Reading can be done anywhere and anytime provided there are desire, enthusiasm and motivation. If this is realized, it is expected that reading can become a part of life that cannot be separated like a slogan that says "no day without reading." When children enter school age, the teacher has a role in developing reading interest which can then improve students' reading habits. Thus, parents and teachers share a very important role in shaping and improving children's reading habits.

There are so many advantages that the student can absorb from reading habit. Reading habit is the powerful and long lasting tool in the development of student academic success. The implication of applying reading as habitual activity is student can expand knowledge and increase focus and concentration.
According to Jack (2008) advantages of reading habit, they are 1) reading habit help the mind perform effectively .2) reading habit helps us develop a good vocabulary 3) reading habit boots intellectual curiosity 4) reading habit means psychological activity 5) reading habit helps reader to have positive mind.

Reading comprehension pass a very complex process that involves components, processes, and the solution for the problems faced to improve the comprehension among the learners. When reading, someone tries to understand the contents of the message of the author contained in the reading. Reading is said to not take place if there is no understanding of the reader. Actually, at a higher rank, reading is not just understanding written symbols, but also understanding, accepting, rejecting, comparing, and believing in the opinions in the reading. Thus, if someone after reading has not been able to retrieve a message ordered by the author, then the process has not been successful.

The fact shows that the School Final Examination questions (UAS) mostly require students' understanding in finding and determining the main thoughts, main sentences, reading graphs, plot / plot, mandate, settings, and so on. Without the ability to read comprehension, it is impossible for students to answer these questions. This is where the important role of reading comprehension is to determine the correct answer. The importance of reading for human life has long been realized. Through reading, new knowledge and insights will be obtained that can improve their intelligence so that people are better able to answer life's challenges in the future. Therefore, reading is still needed as a tool to study various fields of science. Success in reading is very important for students in order to develop academic abilities, expertise, and intelligence; it does not 
doubt that reading is the key to the success of a student. So, in this research there was to find out correlation between students' reading habit and their reading comprehension. Match with the formulation of the problem the research was to find out whether or not there was any significant correlation between students' Reading Habit and their Reading comprehension.

\section{LITERATURE REVIEW}

\subsection{Definition of Reading Habit}

Nilsen (2012) habit is behavior that has been repeated until it is become less automatic, enact without purposeful thinking, largely without any sense of awareness. Habitual of reading habit is a repeat action without concerning why this self-concept must happen. In routinely, regularly repeated and occur subconsciously. Therefore, to become someone who have reading habit; they must always do the action and put the action into practice in daily activities. Silitonga (2015) added that read is to understand and grasp the full sense of (such mental formulation) either with or without vocal reproduction

\subsection{Indicator of Reading Habit}

According to Sutarno (2006) A person who has a reading habit is that the person has become accustomed to and processes for a long time in his life always using a part of his time to read. To measure reading habits from students, indicators are needed to indicate that someone has good reading habits or vice versa. indicator of reading habits the writer adapted from Saepudin (2015) \&Rahayu,Winoto,Rohman(2016)and writer modified as follows:

a. Frequency of visiting the library

The school library is not only a source of facilities but also actively becomes a source of information for its users. As a source of learning and it has an important role for students in adding and expanding knowledge.

b. Frequency of Reading

The ability to read someone is largely determined by the level of frequency (frequency) to read. The frequency of reading is the level of frequency of a person in carrying out reading activities. This means, the more often and more time for reading activities, the more likely the higher the level of ability and the easier it is to understand the contents of the reading. The level of reading frequency will produce a reading habit. Students who have high reading habits will also have higher knowledge and experience when compared to students who have low reading habits

c. Duration to read

Duration/time spent by respondents while reading a book. Everyone has a different working time and free time than others. Therefore, every reader is expected to be able to adjust the reading time accordingly without disturbing other activities. The success of reading is not because of the length but the effectiveness and efficiency. It's better for a while but often and continuously, than for a long time but only once. To form reading habits we must read books in a disciplined manner, both reading books and the duration of reading books. Permendikbud policy applies regulations one of the students' duty is reading min 15 minutes before the teaching and learning process. According to Saepudin (2015) duration of reading every day 30 minutes until 2 hours.

d. The purpose of reading

The purpose of reading in general is:1) reading to get information 2) reading to get understanding 3 ) reading to get pleasure. While the purpose of reading specifically is: 1) Reading to get factual information 2) Reading to get specific and problematic information 3 ) reading to give a critical assessment of one's writing 4) 
reading for pleasure 5) reading fill in leisure time activities.

e. Type and number of reading book

Every reader needs to read different material to improve and become an educated person. According to Galicia (2011, p.56-60) relaxed reading as one of the key habit needed for growth and development. The right reading criteria for high school education level are in the form of skills. With the criteria of education that prioritizes skills, it is expected that teenagers can have independence and responsibility when they reach adulthood. Literature or reading for high school education can be a school package book, a practical way to learn Microsoft (Ms. Word, Ms. Excel, Ms. Power Point), how to quickly type a computer with 10 fingers, how to quickly count in mathematics, UAS / UAN exercise book, How to find identity, and so on. In addition, children in high school education are also given recreational literature or reading in the form of comics, newspapers, magazines, teen stories that are religious and heroic. Not a romance. For example, a book entitled after dark appears in the light of the work of R.A. Kartini, and so on.

\subsection{Definition of Reading Comprehension}

Reading comprehension is the activities of extracting and constructing meaning through written language. In comprehension a written language therewas a mental process the text into meaningful information stored in the mind and the new information while they were reading. Hamidah (2016) said the students can get knowledge from the text that they read. Reading need comprehension to understand the context and got the new information of the text. Reading comprehension was the ability to understand or comprehend the text.

\section{RESEARCH METHOD}

This study was conducted through quantitative method and the design is correlational study. According to Walliman (2011, p. 23), correlation research design is used to examine a relationship between two concepts.

The procedure of this study were, first, preparation of the study; (1) ask permission from mam Henny Yulia, M.Pd and mam Trisilia Devana, M.Pd to be expert judgment or the validators of reading habit questionnaire (2) give questionnaire to expert judgment to check for content, (2) rechecking the number of population and samples, (3) requesting permit to conduct research from the school's headmaster. Second, implementation of the study;(1) give the questionnaire to the sample, (2)give the student reading comprehension test. Third, final steps; (1) analyze the result of the questionnaire and the test (2) Describe the data analysis and give the conclusion as the answer of research question. (3) Construct the research report.

The population was taken from four class of eleventh grade of SMANegeri 1 Madang Suku 3 OKU Timur Academic Year 2018/2019.

In conducting this study the writer used all student of XI IPA as a sample based on certain considerations including: 1. Target of sample in this research is eleventh-grade students.

2. Advice that obtained by the writer from the proposal supervisor.

Based on considerations above the writer used the technique of purposive sampling to choose the sample. According to Sudijono (2009) purposive sampling is techniques for determining research samples based on a number of specific considerations that aim to obtain data later be more representative. The sample is presented in the table 1: 
Table 3.1. The Sample of the Study

\begin{tabular}{lll}
\hline No & Class & $\begin{array}{l}\text { Number of } \\
\text { population }\end{array}$ \\
\hline $\mathbf{1}$ & XI IPA 1 & 30 \\
$\mathbf{2}$ & XI IPA 2 & 34 \\
Total & 64 \\
\hline \multicolumn{2}{l}{ (Source data: } & SMA N 1 Negeri 1 Madang Suku 3 \\
OKU Timur in academic year 2018/2019)
\end{tabular}

Technique for Collecting Data

Arikunto (2010, p. 164) there are five methods in collecting the data. They were questionnaire, interview, observation, test and documentation method. In this study, the writer used two of the five methods; that they were questionnaire and test.

a. Questionnaire

In this study, the data of reading habit were collected by using questionnaire. According to Sudijono (2009, p.164) questionnaire is a set of questions for obtaining statistically useful or personal information from individual. A questionnaire that used in this study is close ended questions. It is enable respondents to answer the question from the available answer in the questionnaire, and the questionnaires were made to measuree the eleventh grade students reading habit. Indicator of reading habits aadapted from Saepudin (2015) \& Rahayu,Winoto,Rohman (2016) as follows:1) frequency of visiting Library,2) Frequency of reading,3) Time to read,4) The purpose of reading,5) type and number of book. The questionnaire is based on theories from experts and modified by the writer. Total of the statement in this questionnaire are 50 statements and writer used expert judgement to assess the validity of questionnaire and according to expert 25 question was appropriate for research. Before give the reading habit questionnaire, the writer validated the test item with try-out as the last step to validate the statement of questionnaire and the questionnaire from the 25 statement the writer used 20 valid items.

b. Reading comprehension test

To know the student reading comprehension the writer used test. According to Arikunto (2010: 53), a test is a tool or procedure used to know or measure something, by means and rules that have been determined. A test is used to collect the data of students' reading comprehension. The test of reading comprehension is an objective test in the form of multiple choice tests consisting 30 items. Before giving reading comprehension test items to the students, the writer validated the items tests by try out in class and the writer used 25 valid items as a test.

\subsection{Validity of the Questionnaire}

In this study, for the questionnaire the writer was used two steps to check whether the instrument valid or invalid, The first step is the writer used expert judgments as validator. The first validator was mam Trisilia devana, M.Pd, and the second validator was mam Henny yulia, M.Pd. The second step is tried out the instrument. The questionnaires of reading habit consist of 25 items.

The writer tried out the instruments which consist of 30 non sample students at SMA Negeri 1 Madang Suku 3 OKU Timur. The validity of the reading test was analyzed by the SPSS 21.00 program. To analyse the validity of the instrument based on the SPSS, the writer determined the significance level (a) of the test was $0,05 \%$ or $5 \%$ from the confident interval $95 \%$, and the $r_{\text {table }}$ of the test was 0,3601 with $(\mathrm{df}=\mathrm{N}-2=28)$. To know whether the test item valid or not the writer conclude two hypothesis

a. If the critical value ( $\mathrm{r}_{\text {obtained }}$ ) was positive and more than $r_{\text {table }}$ it meant the item was valid. 
b. If the critical value ( $\left.\mathrm{r}_{\text {obtained }}\right)$ was negative and less than $r_{\text {table }}$ it meant the item was invalid.

The result of validity the statements was seen in table 2

Table 3.2. The Result Validity of Statements

\begin{tabular}{ccc}
\hline Conclusion & Number of Question & $\begin{array}{l}\text { Total } \\
\text { Number } \\
\text { of } \\
\text { Question }\end{array}$ \\
\hline Valid & $\begin{array}{c}1,2,4,5,7,7,9,10,12,14,15, \\
16,17,18,20,21,22,23,24,\end{array}$ \\
& 25, & \\
In valid & $8,11,13,18,19$ & 5 \\
& Total & 25 \\
\hline
\end{tabular}

Based on the distribution of the table above, the writer found there were 5 items were in valid they were item 8 , item 11 , item 13 , item 18 , and item 19 , and there were 20 items were valid. So, the writer used 20 items for the research instrument.

1. Analyzing Students' Score of Reading Habit Questionnaire

The questionnaire used ranking scale questions or liker scale ( adaptive from : Sugiyono (2014,p. 94), where respondents' answer to the survey the participant are allowed to choose from either a preexisting set of dichomous answer. The questionnaire is intented to measure eleventh grade grade students' of reading habit.There are 20 items in questionnaire. The students are asking to indicate onfive point scale questionnaires. The score being classified as in table 3 .

Table 3.3. The Score Range of Questionnaire

\begin{tabular}{cc}
\hline Score range & Value \\
\hline SS=Selalu & 5 \\
SR=Sering & 4 \\
KD=Kadang-kadang & 3 \\
JR=jarang & 2 \\
TP=Tidak Pernah & 1 \\
\hline (source $:$ Sugiyono 2014)
\end{tabular}

According to Purwanto (1994 p. 94) qualification is determined by observation or questionnaire assessment guidelines .

Formula $=$ score/total score $\mathrm{x} 100 \%=$ result

Table 3.4. The Score Range of Reading Habit

\begin{tabular}{ll}
\hline Score & Category \\
\hline $\mathbf{8 1}-\mathbf{1 0 0}$ & Very high \\
$\mathbf{6 1}-\mathbf{8 0}$ & High \\
$\mathbf{4 1}-\mathbf{6 0}$ & Average \\
$\mathbf{0}-\mathbf{4 0}$ & Low \\
\hline \multicolumn{2}{l}{ Source: Pao $(2016)$}
\end{tabular}

2. Analyzing the Students' Reading Comprehension

To know student score in reading comprehension the writer gave a test. A test is a systematic procedure for observing one's behavior and it with the aid of numerical or category system. A test is used to collect the data of students'reading comprehension. The test of reading comprehension was an objective test in the form of multiple choice tests consisting 25 items. Before giving reading comprehension test items to the students, the writer tried out to validate the items of the tests. There are four options in each item (A, B, C, D). The writer took some texts from the students' English textbook (the 11th grade English textbook for eleventh grade SMA/MA/SMK/MAK). The writer give 1 score for correctly answer and marked 0 for the incorrect answer.

Calculating the score of the students test, the writer used the following formula.

$$
S=\left(\frac{X}{Q}\right) X 100
$$

Where:

$\mathrm{S}$ = Student's score

$\mathrm{X}=$ The number of correct answer

$\mathrm{Q}=$ Total of question

The writer used the score range and criteria. It was shown in the table 5: 
Table 3.5. The Score Range of Criteria

Score Range Criteria

\begin{tabular}{ll} 
86-100 & Very Good \\
\hline $\mathbf{7 6 - 8 5}$ & Good \\
\hline $\mathbf{5 6 - 6 5}$ & Fair \\
$\mathbf{1 0 - 5 5}$ & Poor \\
\hline
\end{tabular}

Source: Nurgiyantoro 2010,p. 253

\section{The Correlation Analysis}

The correlation analysis was used to find out the correlation coefficient of variable $\mathrm{X}$ and variable $\mathrm{Y}$. in this study, the writer used Pearson Product Moment Correlation Coefficient. The writer used the SPSS program. The level of correlation can be seen as Sudijono (2009, p. 180) stated that general coefficient correlation shown in table 6 :

Table 3.6. Size of Correlation Coefficient

\begin{tabular}{|c|c|}
\hline Correlation value & Interpretation \\
\hline $0.00-0.20$ & Very low \\
\hline $0.20-0.40$ & Low \\
\hline $0.40-0.70$ & Moderate \\
\hline $0.70-0.90$ & High (good) \\
\hline $0.90-1.00$ & Very good \\
\hline
\end{tabular}

(Source :Sudijono, 2009, p. 180)

\section{FINDINGS AND DISCUSSION}

A. Research Finding

1. The Results of Reading Habit Questionnaire Score

The data collected through questionnaire and test. The writer gave the reading habit questionnaire to 64 students at eleventh grade on Maret $20^{\text {th }}$ 2019 in SMA Negeri 1 Madang Suku 3 OKU Timur. The questionnaire consisted of 20 items.

The writer also analyzed the data by using statistical and service solution program (SPSS) version 21 to know the highest score, lowest score, mean, and standard deviation of the score. The highest students' score of reading habit questionnaire was 88 and lowest score was 38 . The mean was 60.89 , and standard deviation score was 12, 35984 . The writer contributed the score into table 7:

Table 3.7. The Percentage Score of Student Reading Habit Questionnaire

\begin{tabular}{cccc}
\hline Score & Category & Frequency & $\begin{array}{l}\text { Percen } \\
\text { tage }\end{array}$ \\
\hline $\mathbf{8 1}-\mathbf{1 0 0}$ & Very high & 4 & $6,25 \%$ \\
$\mathbf{6 1}-\mathbf{8 0}$ & High & 28 & $43,75 \%$ \\
$\mathbf{4 1}-\mathbf{6 0}$ & Average & 28 & $43,75 \%$ \\
$\mathbf{0}-\mathbf{4 0}$ & Low & 4 & $6,25 \%$ \\
\hline
\end{tabular}

Based on table above, it could be explained that in very high level were 74 students, 28 students were high level, 28 students were average level, 4 students were low level.

\section{The Result of Students' Score of Reading Comprehension}

The students' score of reading comprehension was gotten by the test. The writer gave the reading comprehension test to 64 students at eleventh grade on February $11^{\text {th }} 2019$ in SMA Negeri 1 Madang Suku 3 OKU Timur. The writer got total score 6644 . Besides that from the table above, the writer also analyzed the data by using Pearson Product Moment Formula in statistical and SPSS version 21 to know highest score, the lowest score, mean score, and standard deviation of the score. The highest students' score of reading comprehension test was 96 and lowest scoring was16. The mean was 56, 9375 and standard deviation score was 19 , 51139. The writer contributed the score into table 8:

Table 4.1. The Percentage Score of Student Reading Comprehension Test

\begin{tabular}{cccc}
\hline $\begin{array}{l}\text { Score } \\
\text { Range }\end{array}$ & Criteria & Frequency & Percentage \\
\hline $\mathbf{8 6 - 1 0 0}$ & $\begin{array}{l}\text { Very } \\
\text { Good }\end{array}$ & 7 & $5,64 \%$ \\
& Good & 12 & $9,7 \%$ \\
$\mathbf{7 6 - 8 5}$ & Fair & 40 & $32,23 \%$ \\
$\mathbf{5 6 - 6 5}$ & Poor & 65 & $52,42 \%$ \\
\hline $\mathbf{1 0 - 5 5}$ & & & \\
\hline
\end{tabular}


Based on table above, it could be explained that in very good level were students, 12 students were good level, 40 students were fair level, and 65 student were poor level.

B. Statistical data analysis

1. The Coefficient correlation

The writer used SPSS 21 Pearson product moment correlation coefficient analysis to find out the correlation coefficient of independent variable (students' reading habit) and independent variable (their reading comprehension). In this research, the writer used SPSS 21 to calculate the correlation between students' reading habit and their reading comprehension. The result of the calculation was shown in table 9:

Table 4.2. Result the calculation

\begin{tabular}{|c|c|c|c|}
\hline \multirow{4}{*}{$\begin{array}{c}\text { readinghab } \\
\text { it }\end{array}$} & & $\begin{array}{l}\text { readinghab } \\
\text { it }\end{array}$ & $\begin{array}{l}\text { readingco } \\
\text { mprehensi } \\
\text { on }\end{array}$ \\
\hline & Pearson & 1 & $.555^{* *}$ \\
\hline & Correlation & & \\
\hline & Sig. (2-tailed) & & .000 \\
\hline \multirow{9}{*}{$\begin{array}{l}\text { readingco } \\
\text { mprehensi } \\
\text { on }\end{array}$} & $\begin{array}{l}\text { Sum of Squares } \\
\text { and } \\
\text { products }\end{array}$ & 9624.234 & 8438.562 \\
\hline & Covariance & 152.766 & 133.945 \\
\hline & $\mathrm{N}$ & 64 & 64 \\
\hline & Pearson & $.555^{* *}$ & 1 \\
\hline & Correlation & & \\
\hline & Sig. (2-tailed) & .000 & \\
\hline & $\begin{array}{l}\text { Sum of Squares } \\
\text { and } \\
\text { products }\end{array}$ & 8438.562 & 23983.750 \\
\hline & Covariance & 133.945 & 380.694 \\
\hline & $\mathrm{N}$ & 64 & 64 \\
\hline
\end{tabular}

Based on the result of SPSS in the table 9 above, it found that the coefficient correlation (r) was 0,555 with the level significance 0,000 . From the calculation above the writer concluded that there was positive and significant correlation between students' reading habit and their reading comprehension. The correlation is medium in term of correlation coefficient was 0,555 and the correlation level of significance was $0,000<0,05$. It meant that the research hypothesis $\left(\mathrm{H}_{\mathrm{I}}\right)$ was accepted and null hypothesis $\left(\mathrm{H}_{\mathrm{O}}\right)$ was rejected. Therefore, there was positive correlation between students' reading habit and their reading.

\section{Interpretation}

Based on the finding in the study, the writer found that students' reading habit was in high category because the mean of the student reading habit point was 60,89 . Based on the result of students' reading comprehension the writer got the students' mean score 56,93, so it meant that the eleventh grade student of SMA Negeri 1 Madang Suku 3 OKU Timur academic year 2018/2019 was in fair category in reading comprehension. The writer could find that there was correlation between students' reading habit and their reading comprehension of the eleventh grade and at SMA Negeri 1 Madang Suku 3 OKU Timur which was in moderate correlation. It meant that the reading habit is not only aspect influenced the level of reading comprehension but there are other factors that influence students understanding of reading comprehension can be influenced by several factors. According to Sumadayo (2011) there are factors that influence students' reading comprehension abilities including: intellectual (related to intelligence), language skills (related to vocabulary, how much understanding of vocabulary is owned), psychological (related to attitudes, interests and emotions), environment (relating to social, economic and cultural background), experience (related to knowledge and habits in reading).

\section{CONCLUSION}

Based on the result of the data analyzing, the writer concluded that there was significant correlation between students' reading habit and their reading comprehension of the eleventh grade and at SMA Negeri 1 Madang Suku 3 OKU Timur in medium level. Not all student 
who got high reading habit score reading got high score in reading comprehension and otherwise because of another factor that influenced the level of reading comprehension there are internal factor and external factor. Internal factor is the factor from student themselves such as intellectual, language skills, psychological, environment, experience and external factor such as facilities that provided at school which not much to support student learning English and limited time to learning English twice per week.

The result of correlation coefficient(r) between reading habit and reading comprehension was 0,555 with the level significance 0,000 . The correlation is medium and the correlation level of significance was $0,000<0,05$. It meant that research alternative hypothesis $\left(\mathrm{H}_{\mathrm{a}}\right)$ was accepted and the null hypothesis $\left(\mathrm{H}_{\mathrm{O}}\right)$ was rejected. Therefore, the writer concluded that there was positive correlation and significant correlation between students' reading habit and their reading comprehension of eleventh grade student at SMA Negeri 1 Madang Suku 3 OKU Timur.

\section{REFERENCES}

Arikunto, S. (2010). Prosedur Penelitian Suatu Pendekatan Praktek. Jakarta: Rineka Cipta

Analytical Exposition Text: Definition, Purposes, Generic Structures, Language Features. 2019. Accessed from http://britishcourse.com/analyticalexposition-text-definition-purposesgeneric-structures-languagefeatures.php

Cohen, L., Manion, L., \& Morrison, K.(2007).Research Methods in Education $\left(6^{\text {th }}\right.$ ed.). London, New York: RoutllegeFalmer
Cresweel, J, W. (2012). Educational Research. 501 Boylston Street, Boston, MA 02116: Pearson Education, Inc.

Destiani, A. Z.( 2007). The correlation between reading habit and reading comprehension on indonesia language subject of fifth grade students at MI ISMARIA Al'quran Bandar Lampung. Thesis.Lampung: UIN RadenIntan Lampung

Doddy, A., Sugeng, A., Effendi.(2008). Developing English competencies 2: for Senior High School (SMA/MA) grade XI.Jakarta :DepartemenPendidikanNasional

Galicia, J. C. G. (2011). Relationship between Reading Habits. University Library and Academic Performance in A Sample of Psychology Students.

Jack, S. (2008). The Habit of Reading and Its Advantages-Why You Should Develops Habit of Regular Reading. International Journal Education Science.

Nunan, D.(2003). Practical English Language Teaching. New York: The Mc Graw-Hil Companies Inc.

Nilsen, P.(2012). Creature of Habit: Accounting For The Role of Habit in Implementation Research on Clinical Behavior Change. Implementation Schience Journal

Acheaw, Micheal Owusu and Larson, Agatha Gifty. (2014). Reading Habits Among Students andits Effects on Academic Performance: A Study of Students of Koforidua Polytechnic. Library Philosophy 
and Practice (e-journal): University of Nebraska-Lincoln

Palani, K. K. (2012) Promising Reading Habits and Creating Literate Social. International Reference Research JournalVol. III Issue 2(1) pp 91.

Pao, B. (2016). The influence of reading habit and grammar knowledge on the students' capability of writing narrative texts.LingTera, 3(2), 122129.

doi:http://dx.doi.org/10.21831/lt.v3i 2.11110

Patel, M.F., \& Jain, P. M.(2008). English Language Teaching. Jaipur:Sunrise

Putra, D. A. K.( 2006). Hubungan antara Kebiasaan Membaca dan Kecepatan Membaca dengan Pemahaman Bacaan Siswa Kelas II SMP Negeri di Kecamatan Depok, Sleman, Yogyakarta. Thesis. Yogyakarta: FBS UNY.

Rahayu, W., Winoto, Y., Rohman, A. S., (2016). Kebiasaan membaca siswa sekolahdasar (survei aspek kebiasan membaca Siswa SD Negeri 2 Pinggirsari di Desa Pinggirsari Kecamatan Arjasari Kabupaten Bandung). Jurnal Ilmu Perpustakaan, Informasi, dan Kearsipan Khizanah Al-Hikmah, 4(2), 152-162

Saepudin, E. (2015).Tingkat budaya membaca masyarakat: studikasus pada masyarat di kabupaten bandung. Jurnal kajian informasi \& perpustakaan, 3(2),271-285.

Silitonga, F. (2015). The vocabulary understanding of reading text in Hosannah Batam School. Journal
BASIS, $\quad 2(2), \quad 111-116$. http://ejournal.upbatam.ac.id/index. $\mathrm{php} / \mathrm{basis} /$ article/view/310

Sudijono, A. (2009). Pengantar Statistik Pendidikan. PT Raja Grafindo Persada: Jakarta.

Sugiyono. (2009). Metode Penelitian Kuantitatif Kualitatifdan $R \& D$. Bandung: Alfabeta angkasa

Sutarno, NS. (2006). Manajemen perpustakaan: suatu pendekatan praktik. Jakarta: Sagung Seto

Tarigan, H. G. (2008). Menulis Sebagai Suatu Keterampilan Berbahasa. Bandung: Angkasa

Thanuskodi, S. (2011). Reading Habit Among Library and Information Science Students. Annamalai University: A Survey, International Journal Education Science

Waliman,N.(2011).Research Method The Basic. United states: Roledg 